$1 G-14$

\title{
エアコン製造工程における 組立にくさの定量評価指標の開発
}

佐々木十太、神代雅晴、三宅晋司、小嶺憲国、赤津順一（産業医科大学）

A New Technique for Quantitative Evaluation of Difficulty in Assembly work.

Tota Sasaki, Masaharu kumashiro, Shinji Miyake,

Norikuni Komine, Junichi Akatsu

(Dept. of Ergonomics, UOEH, Japan)

\section{1.はじめに}

組立ラインにおける作業の難易性は生産性に 大きく影響する。真の効率化を追及するために は作業者にとって組立やすい対象物であること が考慮されていなければならない。そのために は設計段階で種々の人間工学的な配慮が求めら れる。本研究では板金・機能部品の組立工程に 従事している作業者が感ずる組立にくさを、人 間工学的な観点から定量的に評価でき、設計に 反映できる指標の開発を試みたので報告する。

組立にくさは大概 2 つの要因から構成されて いると考え、それに基づいた調査を行った；

·身体的な負担,不具合性から生ずる組立にくさ •精神的な負担,不具合性から生ずる組立にくさ 身体的な側面では主として不良姿勢での繰り返 し作業に着目し、精神的な側面では主として組 立動作の難易度に伴ういらいら感等の不具合さ に着目してそれぞれの定量化を試みた。

さらに、アンケート調査結果から主観的組立 にくさの定量化を行い、前述 2 種のデータと相 互比較し、それぞれの重み付けを検討した。

\section{2. 調查. 分析方法}

\section{2 -1 組立時の負担に関する調査}

対象とした組立作業捝事者は 3 名であり、3 名の作業者の組立部品は図1に示されている1 ー 9の9種類14部品である。(作業者A：1〜4 B：5一テ,C：S，9をそれぞれ担当)

調査項目としては疲労自覚症状調べ、心拍数 を用いた。

\section{2 - 2 組立姿勢に関する調査}

OWAS法による姿勢分析を行った。

\section{2-3 組立動作の難易度に関する調査}

組立動作の難易度分類に関しては要素動作 時間分析を行った。同作業者の1日の作業を VTR撮影し、それを用い要素動作分析を行い 時間值を算出した。動作分析は MTM 法を主 体として実施し、分類できない動作に関して はWF 法の一部を取り入れた本研究独自の標 準時間設定法を用いた。

要素動作の中から組立にくさに関すると思 われる動作を取り上げ、それらの時間值を組 立にくさの指標とした。部品を評価する際に は、全ての組立にくさを合計した時間值の何 $\%$ に相当するかで評価点数を決め、100点満 点からの減点法とした。

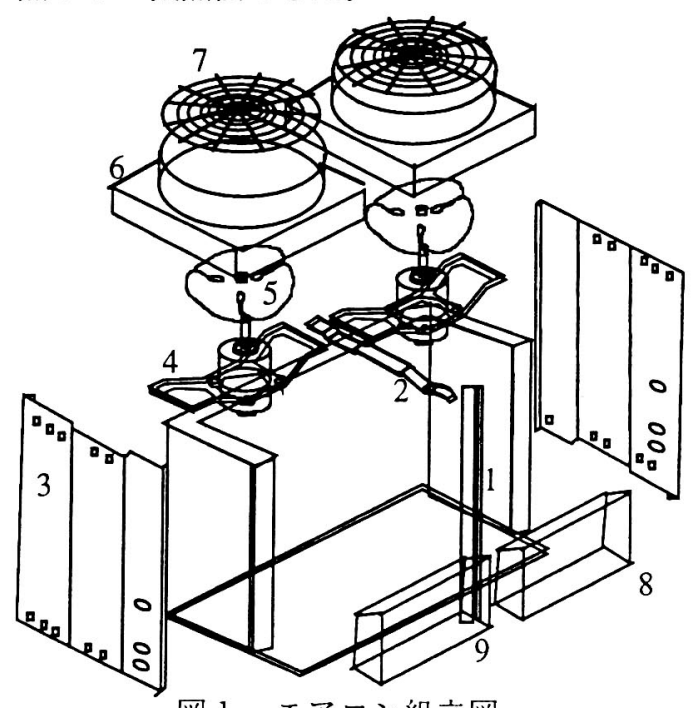

図1エアコン組立図 


\section{$2-4$ 組立にくさの主観的評価点数算出}

作業者が感ずる組立にくさ (身体的側面 +精 神的側面)について、アンケート調査結果から 部品ごとに定量化した。すなわち、あらかじめ 組立を妨害する要因について熟練者たちにヒア リングを行い、組立に大きく影響すると思われ る 6 項目を抽出し、この 6 項目に対して Visual Analogue Scaleによって評価させた。線分上に 印された位置を0〜100の数值として読み取り素 点とし、さらにこれらの 6 項目間の重みづけ は、すべての組み合わせ15通りを一対比較する ことによって求め、この重みづけ係数を上記素 点にかけることにより総合的な点数を算出した。

\section{3. 結果と考察}

1 日の負担調査結果として (1)疲労自覚症状 調べでは、I群(ねむけとだるさ)の訴えが高く 作業終了後にはすべてが 40 \%を超えていた。 さらにIII群(局在した身体異和感)でも作業者 $\mathrm{A}$ が30\%、作業者Cが40\%と高い訴えを示した。 (2)心拍数の変動係数(標準偏差/平均值)で比較 した場合、作業者Aが $10.9 \%$ 、次いで作業者 Cが $9.7 \%$ 、作業者Bが $5.6 \%$ となった。構成部 品組立時の心拍数では $1 、 3 、 4 、 6 、 8 、 9$ 部品 の組立時に100(拍/分)を越える高い値が見ら れた(図 2 )。(3) OWASの結果では、作業者 Aに負担の強い作業姿勢 (カテゴリIII) が 25.6 \%見られた。さらに部品ごとの作業姿勢では 1、3部品組立時にカテゴリIII、4、8、9では軽 い負担感となる姿勢(カテゴリII)が見られ、そ れ以外は特に負担とならない姿勢 (カテゴリI) に分類された。

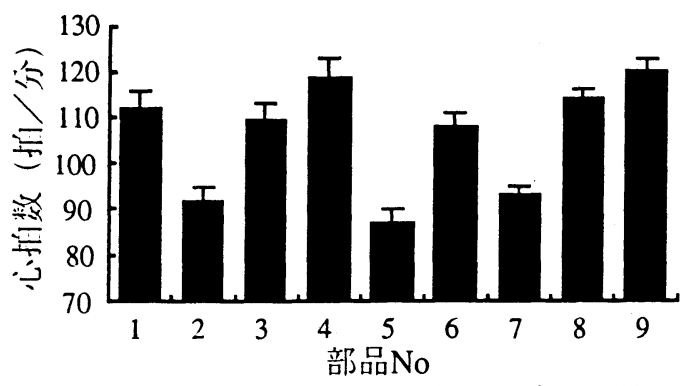

図 2 構成部品組立時の心拍数比較

(4)動作時間分析の結果では、しゃがみ姿勢で の組立で 60.9 ( TMU相当)、中腰姿勢での組立 で31.0、強い圧し(Apply Pressure)が必要な組立 で16.2、組立部品が見えない場所での位置決 めで12と他の組立にくさ要因と比較して大き な時間値が見られた。このような組立にくさ 要因の時間値をすべて累積すると、286.8とな った。(図 3 )

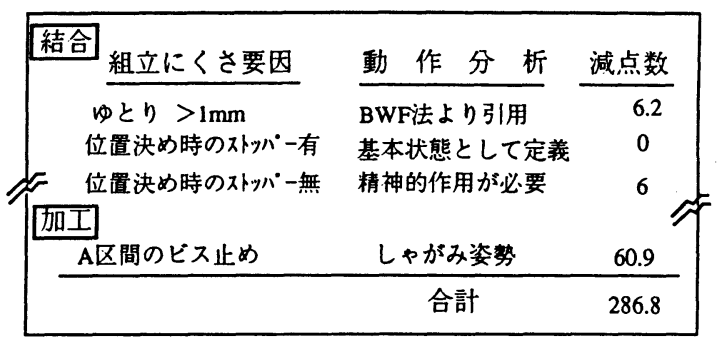

図 3 組立にくさ要因一減点数表

作業者の Visual Analogue Scaleで得た主観的 評価点数と動作時間分析によって算出した評価 点数及び $[100$ 一相対心拍数(\%)] の相関を検討し た。主観的評価点数と $[100$-相対心拍数(\%)]と の間に有意の相関は認められなかったが有意の 傾向が観察された $(\mathrm{P}<0.1)$ 。

動作分析評価点数と主観的評価点数の差の大 きい部品は4、8、9 であり、全て主観的評価点 数の方が組立にくさを大きく評価していた。そ れらの部品組立時の姿勢評価ではカテゴリIIが 示され、心拍数でも高い値を示していた。また $4 \mathrm{Kg}$ を越える重量部品でもあった。すなわち 身体的側面から生ずる組立にくさ要因としては 不良作業姿勢を伴う重量物の影響があることが 考えられた。

\section{4.まとめ}

動作分析で得られた評価点数に重量と不良作 業姿勢による重み付け係数を加えて、新しい組 立にくさ指標 ; EDA法(Evaluation of Difficulty in Assembly work)と称した方法で評価した結果、 主観的評価点数との間で高い相関が認められ( $<0.01$ )、本方法の有効性が示惨された。 